\title{
Dreaming of islands: individuality and utopian desire in post-Darwinian literature
}

\author{
Niall Sreenan \\ University College London, United Kingdom \\ n.sreenan.I2@ucl.ac.uk
}

\begin{abstract}
This paper conducts an exploration of the post-Darwinian literary and philosophical imaginary through the topos of the island. Drawing upon philosophical reflections by Gilles Deleuze on the nature of material islands and their psychic function as fantasies of transcendence, I argue that the island takes on new significance in a post-Darwinian world by offering an image of human independence that is unavailable under the regime of biological evolution. By conducting comparative readings of Michel Houellebecq's The Possibility of an Island, Aldous Huxley's Island, Samuel Butler's Erewhon, and H.G. Wells' The Island of Dr Moreau, instigated by the critical apparatus developed with my reading of Deleuze, I establish the existence of a genealogy of post-Darwinian narratives in which the island facilitates a specifically utopian dream of individual autonomy, which is bound up with the ideology of capitalism. Taken together, I argue, these works emphasise the importance and complex position of the island in the post-Darwinian imaginary. In these works, islands neither allow for simplistic affirmations of such utopian, capitalist fantasies of human sovereignty nor deterministic pessimism, but explore critically these ideas as they co-exist in tension.
\end{abstract}

Keywords: Aldous Huxley, Charles Darwin, desert islands, Gilles Deleuze, Michel Houellebecq, Samuel Butler, Utopia

https://doi.org/10.24043/isj.34

(C) 2017 — Institute of Island Studies, University of Prince Edward Island, Canada.

Trees and islands: models of evolution and criticism

"We are all post-Darwinians." So says Virginia Richter (2011, p. 1) in her recent work on the influence exerted by Charles Darwin's theories of evolution on Western literature and, specifically, on how literary art negotiates the distinction humanity seeks to make between itself and animality. However, Darwin's contemporaries, Richter (2011, p. 7) writes, "recoiled from the theory of natural selection" - not because of scientific objections, but primarily "because man's singular status as a superior being [...] was fundamentally called into question." In turn, related "fears of degeneration, of individual reversions to a more primitive or even animal level, and of the large scale of breakdown of civilization" have become immanent to Western society's collective post-Darwinian unconscious. This assertion of the epochal nature of Darwin's thought is as much a historical and psychical argument as it is an announcement of a particular literary critical approach which responds to the culturally monumental paradigm shift induced by Darwin's work.

As Gillian Beer $(2009$, p. 3) puts it in her influential work, Darwin's Plots, once Darwin's theory of natural selection became popularised, "everyone found themselves living in a Darwinian world in which old assumptions had ceased to be assumptions, could be at best beliefs, or myths, or, at worst, detritus of the past." Just as Freudian psychoanalysis and its concepts slipped into common usage, "disrupt[ing] all possible past patterns for apprehending experience," Darwin's theories of evolution-natural selection, in particular-represent transformative events in human 
thought, whose impact on Western culture and literature in particular is indelible (Beer, 2009, p. 3). Thus, for Beer and Richter both, reading any 'post-Darwinian' work of literature in relation to the conceptual and literary content of Darwin's evolutionary thought, regardless of its direct historical or genealogical connection to Darwinism, is not only critically admissible, methodologically speaking, it is, by implication, an intellectual necessity. All literary art after the emergence of The Origin of Species in 1859 is, implicitly, already either written or understood in relation to a collective cultural unconscious shaped by Darwinian evolutionary theory.

Beer and Richter confirm the episteme-defining significance of Darwin's thought and, tacitly, the value of excavating through creative readings of diverse and unexpected texts this episteme's unconscious assumptions, beliefs, and myths. However, Beer in Darwin's Plots and numerous other critics study solely works of Victorian literature on the basis that they are demonstrably or consciously written in response to Darwin's work (Beer, 2009; Levine, 1988; Shuttleworth, 1984). For Beer (2009, p. 4), this approach springs from a desire to examine and to take into account the specific "act of reading" Darwin and the reaction that act precipitated in works by authors such as Thomas Hardy and George Eliot.

I shall in this paper be taking a different route. Rather than make use, as Beer does, of the critical possibilities of conscious discursive connection, tracing a legible narrative of historical continuity through a literary genealogy of readers and responders, I focus here on a topos which represents radical disconnection: the island. Darwin (1859, p. 489) enjoins us at the conclusion of The Origin of Species to "contemplate an entangled bank, clothed with many plants of many kinds, with birds singing on the bushes [...] and to reflect that these elaborately constructed forms, so different from each other, and dependent on each other in so complex a manner." Such interconnection, Darwin argues, is the basis for the transformations of evolution which act according to laws of inheritance, variation, competition, and reproduction. Beer's broadly historicist undertaking can be understood, in one sense, as a mirror of Darwin's genealogical one: an attempt to understand simultaneously mechanisms of connection and transformation. And there is a similar sense of entanglement and complexity in the network of interpenetrations and relations of mutual transformation among Darwin's work, the writing of his literary contemporaries, and Victorian culture and discourse more broadly (Glendenning, 2007). However, the methodology I seek to employ endeavours to make use of an apparently antithetical image, to focus on the representation in literary art of a nominally ahistorical abstraction, the figure of the island, a notionally sovereign topos, isolated, shorn of connection. In doing so I hope to offer a new point of origin from which to continue to excavate the post-Darwinian unconscious, revealing submerged conceptual relations between apparently disconnected texts and new genealogies of post-Darwinian literature.

My focus on the figure of the island here, understood as an object in opposition to that of the genealogical line or tree, is not solely a methodological conceit. The island is a significant topos-both in the sense of a recurrent theme and imagined place-in the post-Darwinian gestalt. The island, I shall show, is an embodiment of a type of imagined biological independence which is no longer available to humanity after Darwin. This, too, is Richter's $(2011$, p. 8) thesis when she in After Darwin focuses her literary critical explorations on what she calls the literary and philosophical impact of the "anthropocentric anxieties" generated by Darwin's thought. The Origin of Species does not seek explicitly to demonstrate the troubling thesis that the human is biologically united with and derived from the animal. But in Darwin's later work, The Descent of Man, which explores humanity's indissociable biological and historical connection with all other biological life, this argument is made unavoidable (Darwin, 1859, 1871). "It is only our natural prejudice, and that arrogance which made our forefathers declare that they were descended from demi-gods," writes Darwin in the latter text, "but the time will before long come when it will be thought wonderful, that naturalists, who were well acquainted with the comparative structure and development of man and other mammals, should have believed that each was the work of a separate act of creation" (Darwin, 1871, pp. 33-34). Thus, the post-Darwinian world is one in 
which the ontological and bodily sovereignty of the human is constantly under question and in which the very category of humanity, through its connection with animal life, is immanently under threat.

In her reading of H.G. Wells' The Island of Dr. Moreau (2005 [1896]) via Giorgio Agamben's (1998) concept of 'bare life', Richter (2011) recognizes in the novel's eugenically synthesized hybrid animals a kind of uncanny, abject evolutionary horror. Half-man and half-beast, these beings are liminal and transgressive, a kind of life which, according to Agamben (1998, p. 109), is "not simply natural reproductive life, the $z o \bar{e}$ of the Greeks, nor bios, a qualified form of life," but is "the bare life of homo sacer and the wargus, a zone of indistinction and continuous transition between man and beast, nature and culture." Such a type of living being, Richter suggests, is an embodiment of the horror humanity faces as it confronts its own evolutionary origins and, since humanity can be understood as distinct only in opposition to animality, its own death in the wake of Darwin's deconstruction of the notion of independent creation. Furthermore, for Richter (2011, p. 100), Moreau's 'Beast-folk' represent a double kind of 'forgery'. The novel's narrator, Prendick, is a potentially unreliable witness, whose story of the vivisectionist Moreau and his eugenically created half-animal, half-human monstrosities, is considered by others to be highly suspicious (Wells, 2005 [1896]). Thus, insofar as the veracity of Prendick's account of the island of Dr. Moreau and the human-beasts which inhabit it is unverifiable, it is significant that the beasts themselves are a kind of biological creation without essential grounding: the 'Beast-folk' are a form of biological counterfeit, an unreal creation, just as for humanity after Darwin any sense of distinctiveness must itself be a kind of fiction.

The semantic undecidability of the forgery-an uncertainty mirrored by the hybrid, uncanny nature of Moreau's monsters-is only made possible in the novel by the topographical conditions of the island's geographical isolation and its radical disconnection from the world. Moreau escapes to this island in order to conduct his vivisectional experiments in isolation and without interruption, and Prendick finds himself on this unmapped island purely by accident, after he is shipwrecked. Further emphasising the radical isolation of this island, Prendick's rescue occurs only when a boat floats serendipitously ashore to the island, on which he escapes to be picked up by another ship. But even when the island is located, Moreau's beasts are never found and it is for this reason that Prendick's story cannot be verified; a ship visiting the island finds it uninhabited apart from a number of curious, but wholly recognizable, species of rats, hogs, and other mammals. Thus the island first appears as geographically other, as existing outside human understanding and, subsequent to its discovery, potentially fictitious. The isolated and then deserted island of Dr. Moreau, therefore, is itself a kind of liminal case like the 'Beast-folk', a paradox in the light of the interconnected historico-biological materialism of evolutionary theory. For it remains radically apart from and resistant to the genealogical project of evolution, which suggests universal material entanglement as a mode of understanding. At the same time, it is precisely this isolation-which is either fictitious or real-which facilitates the creation of an interstitial and fluid type of biological life that is itself resistant to taxonomical capture or simplistic notions of individual species.

\section{Deleuze's island and evolutionary individualism}

In The Island of Dr. Moreau the deserted island can be read as representative, on the one hand, of a radical discontinuity which, on the other, supports a type of life and meaning which by virtue of the continuity between human and animal life is resistant to representational fixity. This tension is explored further by Gilles Deleuze (2004) in his early, enigmatic essay, 'Desert Islands', which explores the contradiction in geographically materialist and imaginary mythical conceptions of desert islands. A rudimental understanding of island geology, Deleuze argues, shows how islands are geographical exemplars of the liminal, fluid kind of life which Wells' 'Beast-folk' embody from a biological perspective. 'Continental islands', Deleuze (2004, p. 9) points out, are borne of 
derivation and disarticulation while 'oceanic islands' emerge from "underwater eruptions" and coral reefs, "bringing to the light of day a movement from the lowest depths": both remind us that "the sea is on top of the earth, taking advantage of the slightest sagging in the highest structure [and] that the earth is still there, under the sea, gathering its strength to punch through to the surface." Islands, therefore, despite appearances, are never either separate or deserted, but are continuous with and penetrated by the earthly materiality of geological duration, by humanly indiscernible processes of differentiation, emergence, and derivation. They are constituted by the constant interchange between earth and water and in this way embody a differential, unstable ontology.

Just as the 'wargus' is a horrifying image of transgressive biological indistinction, Deleuze (2004, p. 9) observes that humanity finds no reassurance in this conception of the instability and differential materiality of islands, and seeks where possible to repress this fact. To that end, he posits that the popular imaginary figure of the remote and disconnected deserted island is symbolic of a fantasy that 'the active struggle between the earth and water is over, or at least contained', and that, therefore, there exists a space of total stability and emptiness which is amenable to stable (representational) capture. This notion is developed further in his reading of the topos of the desert island in Daniel Defoe's Robinson Crusoe, which asserts that here the imaginary figure of the deserted island functions not only to make possible an anti-materialist, transcendentally grounded conception of the life, but sustains a semi-divine notion of individual agency. "Dreaming of islands," Deleuze (2004, p. 10) writes, is both "dreaming of pulling away, of being already separate, far from any continent" as well as "dreaming of starting from scratch." Crusoe's desert island, like that of Dr. Moreau, is an ideational petri dish, its separation and isolation making possible the growth of a culture, understood as biological life in the latter and human civilization in the former. But in contrast with Richter's and my reading of Dr. Moreau's island laboratory, which produces monstrous semantic or biological diffuseness, Crusoe's island represents a fantasy of reconstituting a world of religious security, certitude, and individualism: the world as the everyday life of protestant, bourgeois, Western civilization (Deleuze, 2004, p. 12). Viewing the desert island as "already separate," as a geographically, economically, historically autonomous terrus nullus, allows Defoe to cast Crusoe's island as an indivisible and autarchic point of origination on which capitalist society and logic can be spontaneously re-generated by the work and effort of Crusoe himself. Thus, Deleuze's reading suggests, the imaginative topos of the deserted island provides the conditions for an unexamined (or, perhaps, disingenuous) transcendental monadism, which itself philosophically underwrites the individualism of Defoe's and Crusoe's shared ideology.

This reading of Defoe's novel is echoed in Ian Watt's analysis of Robinson Crusoe and the genesis and evolution of the novel form in Europe (Watt, 1957). Watt demonstrates how the fantasy of the transcendent creative agency of the homo economicus in Defoe's novel both nourishes and is nourished by the historical emergence of a Puritan, individualist impulse in the late-17th and early 18th centuries. Crusoe, Watt argues, can be read as an archetypal capitalist, whose conception of sovereignty and self-sufficient individualism develops that of the British empiricists of the 17th century, and whose construction of a civilized world from a savage one dignifies Adam Smith's focus on the division of labour in The Wealth of Nations later in the century. Between Deleuze and Watt, then, the literary figure of the desert island takes on a specific form and performs a specific type of work. A notionally transcendent and autonomous monad becomes the setting on which to stage the supreme inventive power of capitalism, while this imagined desert island also becomes a topographical projection, deeply ingrained in Western culture, of the isolated and atomized but autonomous and empowered capitalist subject.

Deleuze criticizes Robinson Crusoe as a tedious fantasy of the desire of the capitalist bourgeoisie, and laments its continuing popularity in contemporary children's curricula; but he does not dismiss the novel outright. Instead, he elaborates how the novel-like The Island of Dr. Moreau-deflates its own fantasy of ex nihilo creativity which powers Crusoe's belief in his own individual autonomy. While indistinct ontological status of the 'Beast-folk' repudiate any simplistic conception of the island as transcendent isolate in Wells' text, Deleuze shows how Robinson Crusoe 
contains a disavowed historically and economically materialist conception of life in its account of Crusoe's re-creation of civilization. The resources with which Crusoe builds his lodgings and his new life are not generated spontaneously from the island itself; they are instead derived and re-made as valuable from already extant materials. "Everything is taken from the ship. Nothing is invented. It is all painstakingly applied on the island. Time is nothing but the time necessary for capital to produce a benefit as the outcome of work. And the providential function of God is to guarantee a return" (Deleuze, 2004, p. 12). This theological Marxist retelling of Crusoe's resourcefulness-the creation of surplus value through labour-illustrates how the narrative of the novel undoes the ideological dream it is meant to sustain. However, Deleuze's endeavour in this essay does not terminate with an abstract diagnosis of the Western imaginary's neurotic attachment to and espousal of individualist, capitalist idealism or, indeed, with a deconstructive flourish on the auto-critical capacity of literary art. Instead, the Marxist tenor of Deleuze's reading of the island here indicates an early attempt by him to sketch out a materialist philosophy of becoming which both seeks to establish a universally fluid and indistinct type of ontology, such as is found in Agamben's 'bare life'; and, moreover, to articulate a theory of creative differentiation and individuation which accounts for the emergence of actual material isolates-to geographical islands, to species, and human individuals human individuals-without falling into idealism.

In his later major philosophical work, Difference and Repetition, Deleuze develops his engagement with the relation between being as indistinction and fluidity (difference) and individual, material (differenciated) beings (Deleuze, 1994; Del Lucchese, 2009). Deleuze argues for a concept of the individual which is focused first on the process by which it is generated-individuation - in order to avoid the presupposition that the individual form precedes its creation. "The individual is neither a quality nor an extension," Deleuze (1994, p. 323) writes, as such a conception would rely on a transcendental understanding of differences and individuals as opposed to the differential conception of materiality his philosophy espouses: instead, "qualities and extensities, forms and matters, species and parts are not primary; they are imprisoned in individuals as though in a crystal." Here the individual is not the isolated, monadic human subject or biological being, but a dynamic whole, "a crystal ball." In this, qualities, extensities, or individual beings and subjects are immanent, undergoing constant differentiation; any attempt at the extraction of a single, sovereign, or final individual shatters its unity, and re-enacts of the transcendental delusion Deleuze's materialism seeks to repudiate.

The implications of this philosophical position are developed and clarified in Deleuze's commentary in Difference and Repetition on Darwin's theory of evolution. Here, he argues that Darwin's innovation in biology was not its enhancement of biology's accuracy, to the benefit of classification, but the opposite. With natural selection, Darwin brought into the realm of biology the notion of 'individual difference', understood in this instance as the irreducible individuality of all beings within a univocal whole-as opposed to the mere surface differences between individuals with which taxonomy concerned itself heretofore.

The great taxonomic units-genera, families, orders and classes-no longer provide a means of understanding difference by relating it to such apparent conditions as resemblances, identities, analogies and determined oppositions. On the contrary, these taxonomic units are understood on the basis of such fundamental mechanisms of natural selection as difference and the differenciation of difference. (Deleuze, 1994, p. 248)

Taxonomy after natural selection, therefore, becomes an ossified representation of a dynamic and uncertain processual biological world. In 'Desert Islands', Deleuze anticipates this theoretical position in geographical terms, arguing that the actual existence of material islands, like the existence of individual organisms, is a negation of the idea that islands (and animals) represent spaces of completion and closure, because we know they are constituted by material processes of 
differentiation. Islands are, by definition, never deserted-just as animals are never entirely sovereign-because they are never ontologically separate from the rest of earth: a continental island becomes disarticulated from a larger body of land; an oceanic island rises from geological depths to break the water's surface. These geo-oceanic dynamics tell us that the very conditions which make islands possible also make their transcendent finality as well their desertedness through radical separation impossible. The island, therefore, represents the biological flux in all its monstrosity, embodied by Moreau's 'Beast-folk' as opposed to Crusoe's Puritanical capitalist desert-island subject. However, where the isolation of Wells' island is what stages the creation of the subversive, biologically indistinct hybrid, Deleuze's island is itself premised on the perpetual play between material forces, which ensures that it can never be said that an island exists (being), but only that it is relentlessly in the process of coming into and fading out of existence (becoming).

Elizabeth Grosz's (2011) reappraisal of Darwinian evolution in relation to the politics and philosophies of sexual difference, Becoming Undone, develops this reading of Darwin's evolutionary thought through the prism of Henri Bergson as well as Deleuze. In this, she suggests that the deep misunderstanding of the nature of individuals and thus islands Deleuze finds in Robinson Crusoe also afflicts contemporary affirmations as well as critiques of Darwinism. Echoing Richter, Grosz argues that after Darwin's evolutionary thesis the human should be understood as an ontologically uncertain object: an historical, differential, and durational entity which exists as both an individual and a process of individuation, always in the course of emerging from the past and dissolving into the future. Life, Grosz says, '[is] a kind of contained dynamism, a dynamism within a porous boundary, that feeds from and returns to the chaos which surrounds it' (Grosz, 2011, p. 27). Taking up Deleuze's analysis of Darwin in Difference and Repetition, Grosz argues for a concept of the human in which it is understood that processes of differentiation and individuation are ontologically primary, where forces of evolution precede and outlive organisms and individuals, and where the individual is understood, like the island, to be a durational and contingent material entity.

Grosz suggests that such an understanding of humanity through Darwin could represent a powerful rebuke to biologically essentialist conceptions of sexuality and wider delusions of human transcendence. In light of Deleuze's reading of Robinson Crusoe, it would also by extension address the conditions these fantasies provide for of a capitalist culture of destructive societal individualism and atomization. However, such a conception of evolution and the differential nature of human individuality and biological life is not generally shared by contemporary Darwinian science. Stanley Shostak argues in his Evolution of Sameness and Difference that what he calls 'ordinary science' (by which he means mainstream, institutional scientific practice) has largely become concerned with mobilizing Darwinism for the naïve realist project of ordering the world and to determine how human nature is governed primarily by biology. Shostak (1999, pp. 39-40) asserts that, contrary to any properly radical conception of Darwinism which places at its heart the immanence of difference, in 'ordinary science' difference is, more often than not, subjugated to sameness, that is, as a series of resemblances, identities, or oppositions. In this way, life as a process of difference is ignored in preference for life as an object defined by transcendentally anchored differences. This allows a contradictory biocentric and anthropocentric Darwinism to flourish, providing the ideological foundation for the usage of natural selection's insights for purely instrumental purposes: the protection of human interests, particularly through profit-making biological commerce, and the collusion between those industries and the state in the interest of biopower. Through Darwin, therefore, contemporary life sciences in alliance with capitalism finds a way not just of repressing the processual, differential nature of life, but also to reaffirm humanity's central place as a sovereign: both within nature and capable of transcending it.

Steven Shaviro's essay on 'Interstitial Life' suggests that it is precisely the radicalism of Darwin's theory of evolution by natural selection that causes the paradoxical return of a transcendent concept of species. Darwinian evolution, Shaviro (2010, p. 132) argues, posits an 'immanent, nonteleological mechanism for the development of life', which in the absence of a transcendent creator, assumes a form of organic self-creation. In other words, without an 
exogenous causal instigator, in the form of a transcendent creator (in whose divine image humanity is itself made), a new form of self-activating or 'autopoietic' creative causality is required. It is in part, therefore, the philosophical difficulty of re-thinking the very nature of causality, of negotiating the idea of immanence and autopoiesis, which leads ordinary science towards a renewed teleological and transcendental conception of the creation of life. In particular, the "mainstream Neo-Darwinist synthesis," which Shostak critiques for its close relationship with capital, defends its explicitly teleological thinking as 'an epistemological necessity', re-entrenching the primacy of representation over difference that Deleuzean and Darwinian conceptions of life attempt to positively deconstruct (Shaviro, 2010, p. 141).

As a response, Grosz (2011) argues that it is vital the humanities move past its usual critiques of biological essentialism, and reductionism, to engage with the Deleuzean conception of evolution as a form of becoming. It is important, she argues, because without a positive project for understanding biological indeterminacy coming from critical philosophy, the human sciences can easily repudiate the humanities' understanding of biology, while implicitly adhering to a fixed and complete desert island ontology of the human against which its own most radical concept-evolution-argues most forcefully. For Grosz, this is not merely necessary for the purpose of rooting out philosophical or ideological contradiction. Hers is a politically engaged project, which places a re-engagement with Darwin at the centre of feminist conception of difference. The animal, Grosz $(2011$, p. 12) argues, is understood to be incapable of rationality, of reflection, and, therefore, of ethics-and this distinction is extended metonymically to women, children, slaves, and others, as "the alignment of the most abjected others with animals is almost ubiquitous." Feminist philosophies of difference, in particular, she says, are guilty of disregarding the value of Darwin's work by seeking to address its complicity in numerous intersections of forms of oppression, while ignoring the assault it makes on humanity's primary narcissism-its difference from the animal. But because our self-ascribed humanity is both necessary to our being and sits at the root of myriad forms of other oppression, critically engaging with these forms-and Darwinism itself-demands a laceration of ourselves and the human as a concept.

This problem, Grosz notes, was anticipated by Derrida (2009, pp. 182-183) who in his late series of seminars on The Beast and the Sovereign perceived that of all the blows to the human ego in the history of ideas-from Copernicanism to Freudianism itself-Darwinism was the most threatening to humanity's sense of sovereignty. Derrida suggests that it is only the singular power of human narcissism which reproduces the myth that humanity's capacity to "efface its own trace," to repress its ancestral animality, or to judge as to the success of the effacement, is what distinguishes 'man' from its evolutionary forebears. This "subtle form of phallogocentrism," Derrida (2009, p. 183) writes, reinstitutes the anthropocentric conception of human as a sovereign subject and is, in part, a response to the 'panic' induced by Darwin's theory of evolution. Anticipating Richter's argument that the monsters of Dr. Moreau represent the horror of humanity's biological indefiniteness, the animal, Derrida intimates, echoing Grosz, is held by humanity in a position of absolute wretched otherness in order to reconstitute its own superiority. In this way, rather than wholly reject Darwinism, so called 'ordinary science' can avow its scientificness and hail its predictive power but disavow its assault on human transcendence, mobilizing instead the economic, scientific, and epistemological prestige of Darwin's name in order to further shore up a Robinsonian sense of individual sovereignty.

In the following sections, I continue to examine the contradictions that flow from the tension between Darwinism as a theory of becoming and the individualism it seems to nurture, and how they coalesce around and are reflected in the literary topos of the island. My aim is to show how my theoretical elaboration of the relationship between islands-both imaginary and real-and the post-Darwinian imaginary allows us to uncover a genealogy of island narratives in literature, to which questions of biological evolution, human sovereignty, and capitalist individualism are central. Starting with Michel Houellebecq's The Possibility of an Island (2007), 
and concluding with Samuel Butler's Erewhon (1970 [1872]) and Aldous Huxley's Island, I shall demonstrate how in each of these texts the island represents the only hope for human autonomy after Darwin, and is, simultaneously, also revealed to be a purely fantastical notion, driven by narcissistic and economic individualism.

\section{The Possibility of an Island: evolutionary utopianism and the individual}

The tension between humanity's desire to become a desert island, the individualism of capitalist ideology, and their relation to Darwinian evolutionary thought is one of the subjects of Michel Houellebecq's (2007) recent novel, The Possibility of an Island. This science-fictional roman à thèse tells the story-or stories - of three characters, Daniel1, Daniel24, and Daniel25, three iterations of a notionally single consciousness. The latter two characters are cloned, genetically modified, 'neo-human' duplications of their originary identity, Daniel1, living in a distant future shattered by total environmental and civilizational collapse. Daniel1's narrative is an autobiographical account of his career as a cynical and obscene comedian; details his disillusionment with and hatred of the world; and depicts his resulting drift towards a techno-religious cult, the 'Elohimites', whose research into genomics and human cloning makes biological immortality theoretically achievable. The narratives of Daniel24 and, after his death, Daniel25, describe the lives of Daniel1's clones who seek to construct a transhistorical form of identity by reading Daniel1's autobiographical testimony, in response to which they compose their own future-oriented exegetical commentaries. The novel continuously oscillates between the individual narratives and testimonies of Daniel1, Daniel24, and Daniel25, each of which is implicated in the other, and in this way sets up a dialogic configuration between times, between consciousnesses, and between texts, suggesting in its form the dynamic tension of the Deleuzean island, an individual whose very being is premised on their place in a larger network of relations. There are three islands and one; a mirror of the Catholic conception of the trinity; each of which is independent at the same time as it is dependent on the other for its existence.

John McCann (2010, p.174) notes how this novel's intricate, theologically redolent form is also structurally homologous to the double helix model of human DNA and that this structural conceit echoes the central thematic focus of the novel, the utopian possibilities of evolutionary biology and genomic technology. The 'neohuman' race is constituted by a scattered population of former Elohimites, each of whom live in individual, hermetically sealed compounds-architectural desert islands. These compounds protect them from the climatically hostile external environment which is populated by hordes of wretched, violent non-genetically modified humans-the remainders of their genetic and cultural past. The neo-humans do not require food or water to nourish themselves; they have been genetically modified to derive nutrition from minerals latent in the atmosphere and, thus, neither introject nor excrete any physical matter. And they do not require sexual relations to reproduce; at the expiry of each clone, a newly minted body is delivered to the compound from a centralized cloning centre, at which point that iteration takes up the endeavour of reading and commenting upon the life stories and commentaries of each of his predecessors, extending their shared consciousness(es) indefinitely. So the body of the neo-human is a hybrid of Moreau's forged Beast-folk and Defoe's desert island subject: a eugenically synthesized organism that employs the possibilities of evolutionary fluidity to construct a bio-architectural embodiment of its opposite: total historical and evolutionary stasis. The neo-human is an echo of the cell in which it lives, a repudiation of the system of textual interchange upon which it subsists: a sealed, sovereign monad, excised from the biological world in which it lives-and to which it no longer has any relation except in the form of negation.

A life defined by biological eremeticism is intended, therefore, as a techno-biological answer to the problem posed by Darwinism: Richter's 'anthropocentric anxieties', the horror of biological uncertainty, the destruction of the human island. "Closing the brackets on becoming," Daniel25 observes, "we are from now on in unlimited, indefinite stasis" (Houellebecq, 2007, p. 372). No 
longer subject to the vicissitudes of evolutionary change and, in turn, mortality, the neohuman synthesizes anthropocentric transcendence, untroubled by the horrors of natural selection. However, by contrast, neohuman existence, in its affective and social aspects, appears less as a solution to the problem of evolution and more redolent of a kind of nihilistic withdrawal. Daniel24 and Daniel25 live out their lives in quiet contemplation, socially isolated from other neohumans (apart from periodical exchanges carried out in code), emptied of all forms of desire and even nostalgia for desire itself. Deleuze's reading of Robinson Crusoe predicts this tension, indeed argues that withdrawal is precisely the point. Crusoe requires a desert island in order to reconstitute Western bourgeois culture and thereby to reaffirm individualist capitalism's transcendent civilisational value. Similarly, in Houellebecq's work, remoteness in the sense of biological as well as social and affective withdrawal is the necessary corollary of a desire for human perfection and stability premised on negating evolutionary change. Vincent, the eventual leader of the Elohimite cult, postulates that escaping from Darwinian law will allow humans to flourish in their highest, most creative form. "Man," he argues, "had a large brain, disproportionate in relation to the primitive demands arising from the struggle to survive, from the elementary quest for food and sex": neohumanity would allow each of them to become a true 'individual' without having to "worry about his survival" or "to be constantly on his guard" (Houellebecq, 2007, p. 280). To transcend becoming, the neohuman must also excise itself from the social relations that are inherent in evolution which, in the close interrelations of Darwin's entangled bank, include competition as well as sexual reproduction and, thus, desire.

For Fredric Jameson this type of withdrawal-in this case, from desire itself-springs from a form of desire: the utopian impulse. Writing on the concept, practice, and textual production of utopias, Jameson (2007, p. 4) elaborates upon the everyday, unconscious enactment of fantasies of independence and identifies explicit utopian projects in literature and politics as being defined by an absolute "commitment to closure (and thereby to totality)." Such an impulse, Jameson argues, finds itself expressed in, and is symptomatic of, a less-well articulated, universal-but ultimately banal-desire for individual purity. This can be seen, Jameson (2007, p. 6) says, in "even the most subordinate and shamefaced products of everyday life [...] aspirins, laxatives and deodorants, organ transplants and plastic surgery, [which] all [harbour] promises of a transfigured body." This is Deleuze's desert island thesis enacted in bodily and material form: the subject scours its body of all discernible forms of relation to its environment, casting itself as a transcendentally autonomous space in which to re-invent itself. Similarly, Houellebecq's desert island fantasy, his neo-humans, embody the convergence of the idea that humanity is incapable of dealing with-indeed, is horrified by-its own uncertain, biological ontology and its symptomatic positive response: the utopian impulse - seen also in Robinson Crusoe-to re-create a new, perfected, atomized form of life.

What Houellebecq's high-tech, genomic, state of utopian suspension seeks to achieve, then, is a finalised form of biological flawlessness latent in the very idea of humanity's individuality. However, unlike Jameson's cosmetics, what neo-humanity offers to negate is biological change in its most foundational forms: evolutionary transformation via natural selection and death as well as creative change through sexual desire and reproduction. More than that, neohumanity offers an escape from life under the intersection of evolution and capitalism. Daniel1's misery, his misanthropy, as well as the widespread malaise that leads to the worldwide popularity of the Elohimite cult and its espousal of consensual suicide, is a symptom of all forms of relation being hegemonised by the brutal logic of a capitalist interpretation of Darwinian evolution. An increase in deaths among the elderly in hot Summer weather is viewed as a "natural means of solving the statistical problem of an increasingly aging population." Teenage magazines seek to exploit the "primitive mechanisms" of sexual desire, according to which sexual attraction is premised on an individual's capability to kill other beings (Houellebecq, 2007, p. 41). Thus, individual self-interest takes precedence over social altruism; "the regulation of sexual relations on the model of the so-called free market has resulted in [a] world of sexual consumers, as brutally uncaring as they 
are happy-go-lucky;" and awkwardly valueless members of society-the elderly in particular-are brutally sidelined in favour of the young, who not only embody superior sexual value, but have themselves internalized the competitiveness of the Darwinian paradigm which society has thrust upon them (Best \& Crowley, 2007, p. 205).

What Daniel1 and his peers in the Elohimite cult seek to negate through the creation of a utopian desert island is the misery of this form of relation which, it is understood, can only be conducted in terms of a social Darwinian logic of competition and individual self-interest. The paradox of the neohuman utopia, then, is not merely that it seeks to escape the affective and social consequences of capitalist atomization through an amplification of its individualism. It is also that it seeks to achieve utopian isolation from Darwinian materialism through the intensification of its dynamics of change- a development which they increase in speed through the evolutionary technology and genomic engineering. In other words, to become a desert island, the Elohimites do not simply covertly disavow the processes of individuation and differentiation which bind them in evolutionary life to relating to others-either through biological and economic competition or sexual relation. Instead, they seek to mobilise those forces, to intensify them, and bring them to a conclusion that suits their desire for utopian transcendence: definitive biological separation from the entanglement of evolutionary change; the finalised individual.

\section{Erewhon and Island: Darwinian utopias of the 19th and 20th centuries}

Houellebecq's suggestion in The Impossibility of an Island that the utopian possibility of the finalised biological individual is paradoxically within reach by accelerating the very evolutionary laws which seem to make it impossible is a challenging one. Not only does it appear to question Deleuze's argument that the individual is an inherently ephemeral entity, but it also asks its readers to consider their own complicity, through their own utopian desire, with a biological and economic complex that leads to a dystopian state of affairs, in this novel and in our own world. In this respect, Houellebecq's novel is a distinctively contemporary one, using the singular possibilities of genomic technology as well as the intensely competitive logic of neoliberal capitalism to make its point. However, this novel echoes two earlier novels, from the 19th and 20th centuries, both of which place Darwinian evolution - and its implications for human society and individuality - at the centre of literary philosophical investigations into the possibilities of geographical and biological islands.

Samuel Butler's (1970 [1872]) partly satirical novel, Erewhon, tells the story of an unnamed protagonist who, in the process of seeking to discover and claim land in New Zealand with which to enrich himself, stumbles upon an isolated, hermetic country which, at first glance, seems to be characterised by utopian plenitude, serenity, and stability. Erewhon is surrounded on all sides by a vertiginous mountain range which seals the country off from its external environment, making it, in effect, an inland island. Further to this, this country actively polices its borders with a set of grotesque, threatening statues, designed to ward off potential interlopers. It is an island then-a utopian enclave-whose economic and social isolationism, its physically beautiful people, Arcadian architecture, and quaint, pre-technological way of life seem to represent nothing other than a reverse image of and rebuke to the competitive, capitalist, imperialist industrial late-19th-century Britain from which the novel's protagonist has travelled.

This image comes to be shattered. As our protagonist becomes an fait with the political, social, and economic system of Erewhon, it becomes clear that, although their country is borne of utopian isolation, its success as utopia is questionable. What our protagonist finds is a country remarkably similar to the one from which he came: ruled by a venal elite, where illness is punished as a criminal offence, financial corruption is treated with empathy, and where banks and finance have taken the place of religious icons and faith. But it is also revealed that the pastoral nature of this country is the consequence of a brutally repressive regime that has destroyed all machinery and banned all forms of technological progress. So while Erewhon's supposed negation of 
Victorian Britain turns out to be a kind of mirror image of the capitalist logic of the struggle to survive with which the Victorian age in England is associated, it also seems like a direct repudiation of the spirit of industry and technology which nurtured and is nurtured by capitalism.

The apparently paradoxical nature of Erewhon, however, derives from a coherent and specifically utopian ideology which, as with Houellebecq's neo-humanity, has its origins in a desire for transcendent isolation and the scientific possibilities of Darwinian evolution. The justification for the destruction and abolition of all forms of technological advance is put forward in a text, quoted at length by the novel's protagonist, entitled The Book of the Machines, adapted by Butler (1914 [1863]) from an earlier essay entitled 'Darwin Among the Machines'. In this former text, Butler speculates upon the cataclysmic consequences of technological evolution, were it to proceed in the same manner as biological evolution. Machinery, he argues, has an evolutionary advantage over humanity because:

the machine is brisk and active, when the man is weary; it is clear-headed and collected, when the man is stupid and dull; it needs no slumber, when man must sleep or drop; ever at its post, ever ready for work, its alacrity never flags, its patience never gives in. (Butler, 1970 [1872], p. 205)

However, Butler's evolutionism was heterodox. Rather than dread death by the struggle to survive, we should instead fear the integration of the human body into circuits of non-human reproduction and, thus, the definitive loss of human sovereignty (on which the category of the human is based) at the hands of technology. This differs from Houellebecq's novel, in which the competition of natural selection has become synonymous with a brutal form of sexual competition. Instead, machines, Butler asserts, 'will rule us with a rod of iron, but they will not eat us; they will not only require our services in the reproduction and education for their young, but also in waiting upon them as servants.' The human, having become a subordinate organ in the assemblage of the inhuman being, loses its status as human and thus its own utopian sense of purity. Like the hermetic compounds in which the neo-humans of Houellebecq's novel live, Erewhon's border policing, its attempt to remain undiscovered by other societies, is a geopolitical projection of this Utopian impulse for autonomy, stability, and safety from change. And its destruction of machinery, like the genetic modification of the neohumans, is itself an intervention in evolutionary development-an intensification of corporeal individualism-through which the human attains a state of evolutionary sovereignty.

Aldous Huxley's novel Island (2005 [1962]) bisects the historical distance between Houellebecq's The Possibility of an Island and Butler's Erewhon, constructing a genealogy of imaginary post-Darwinian island utopias spanning the 19th, 20th, and 21st centuries. In its opening pages, the novel alludes to its genealogical predecessor metafictionally: the novel's protagonist who, like that of Erewhon, happens upon an isolated, hermetic island nation, urges his interlocutor-and usto recall "'the beginning of Erewhon" (Huxley, 2005 [1962], p. 22). Subsequently, the novel unfolds a markedly similar narrative to that of Erewhon. The novel tells the story of the discovery by a Western man from London who has designs on the colonial exploitation of an isolated and strange utopian country whose customs appear antithetical to those of his culture of origin. This country is called Pala, an island apparently somewhere near Indonesia which appears, like Erewhon, to work as a negation of the ideologies, conditions, and values of British, Darwinian capitalism.

Also like Erewhon, however, Pala's utopian isolation is paradoxically indebted to Darwinian thought. Pala claims to have created a successful politically autarchic, economically isolationist polity that derives its stability and serenity to structures of social organisation based on an application of Darwinian evolutionary theories, and the elevation of biological science to the status of a religious creed. This "new wisdom," they say, is "biological theory realized in living practice, is Darwinism raised to the level of compassion and spiritual insight" (Huxley, 2005 
[1962], pp. 193-194). Practically, this translates into eugenic breeding controls for humans and non-humans, enabling the genesis of "a child of superior quality" with selective reproductive planning (Huxley, 2005 [1962], p. 183). It also negates the necessity for external economic and political relations by genetically improving crops. These practices, combined with a faith in 'rational' Buddhism, allows the island and its inhabitants to remain biologically and politically separate from the world, and from its aggressively expansionist industrial neighbour, the Polynesian island of 'Rendang'. Like Erewhon and Houellebecq's neo-humans, the Palas' utopian desire for transcendent individuality, at the level of society at least, is made possible not through their rejection of the biological materialism of Darwinism, but through harnessing its biological and technological possibilities.

\section{The impossibility of the desert island}

What each of these novels seems to suggest is that, contra Grosz's and Deleuze's conception of evolutionary becoming and of the biological individual as a processual object, the desert island is not just a fantasy; it is a material, biological possibility. Moreover, these novels impress upon us that the desert island's conditions of possibility are constituted by humanity's anti-evolutionary fantasy of biological autonomy which co-exists with its development of evolutionary science and technology. Even in the case of Erewhon, where, unlike Island and The Possibility of an Island, autonomy is made possible by the destruction of technology rather than its development, the impulse for biological sovereignty is primary. And it would also be a mistake to compare their Ludditism with the rejection of technology in its totality, since like the neohuman they only adopt technical artefacts, such as the statue sentinels that guard their borders, in order to shore up their autarchic isolation.

I have left it to the conclusion of this essay, however, to examine how at the end of each of these novels shows the collapse of these individual islands and, thus, how they return us to the critique of transcendent individuality in Deleuze's essay with which I began. For Pala, the end of utopian autarchy ironically comes about as a result of their own failure to understand how the Darwinian struggle to survive inspires the actions of the imperialist neighbouring country of Rendang and, furthermore, how the naïve, pacifist Palanese understanding of Darwinian evolution leaves them open to attack. The novel ends with tanks from Rendang arriving on the island, its invasion having being partly facilitated by the Palanese heir to the throne whose betrayal of his people, in a final irony, was inspired by the temptations of the very capitalist consumerism which the Palanese island sought to escape. Imperialism, he argues, is not a deviation from the principles of evolution, but the logical conclusion of the Darwinian revolution which Pala itself embraced wholeheartedly. The conclusion of Erewhon is analogous. Having escaped to England from Erewhon in a hot air balloon, the novel's protagonist outlines his plans to return to the inland island with a fleet of ships, with the intention of colonising the country and co-opting its population for labour. He understands that, without any form of contemporary machinery or technology, the Erewhonian utopia is particularly vulnerable to attack. In Houellebecq's novel it is the network of textual interchange that undermines Daniel25's isolation: reading Daniel1's account of the simultaneous pain and joy of human relation leads him to leave his compound in search of others like him. Here, the failure of the neohuman understanding of evolution is different to that of Pala and Erewhon. Here it is assumed that the human can subsist at an affective level as an individual, as a pure, rational, and isolated island, whose interests lie in being transcendent-as opposed to being evolutionarily, materially contingent. It is this misprision of Darwin's thesis, the re-insertion of the human at its centre, which leads to the downfall of their biological utopia.

These three novels, as well as Wells' The Island of Dr. Moreau, form a notable transhistorical genealogy of literary island narratives engaged in questioning human autonomy, the implications of capitalism, and the impact of Darwinism-each doing so by placing the theoretically monadic figure of the island at their narrative centres. This emphasises the importance of the island as a 
literary spatial topos and connects them, implicitly, with older island narratives engaged in similar thematic explorations such as Defoe's Robinson Crusoe. This also suggests that Richter's thesis on the rupture to anthropocentrism made by Darwin in the middle of the 19th century adds a newly biocentric valence to the more fundamentally existential problem of the island and human autonomy. Most importantly, these novels draw upon the dialectical dynamism of the island to pursue an irresolvable point. Each raises the possibility of an island, of a truly autarchic utopia, of a transcendent human-acknowledges its draw, even suggests its viability-while ultimately revealing it as fantastical. This is at once a troublingly pessimistic affirmation of Darwin's evolutionary thought, as well as, nevertheless, a heartening testimony to the persistence of utopian hope in the face of total biological fatalism.

\section{References}

Agamben, G. (1998). Homo sacer: sovereign power and bare life. D. Heller-Roazen (Trans). Stanford, CA: Stanford University Press.

Beer, G. (2009). Darwin's plots: evolutionary narrative in Darwin, George Eliot and nineteenth-century fiction (3rd ed.). Cambridge: Cambridge University Press. https://doi.org/10.1017/CBO9780511770401

Best, V., \& Crowley, M. (2007). The new pornographies: explicit sex in recent French fiction and film. Manchester: Manchester University Press.

Butler, S. (1914 [1863]). Darwin among the machines. In S. Butler \& R. Streatfield (Ed.), A first year in Canterbury settlement with other early essays (pp. 180-185). London: A.C. Fifield.

Butler, S. (1970 [1872]). Erewhon (P. Mudford, Ed.). Harmondsworth: Penguin

Darwin, C. (1859). On the origin of species by means of natural selection, or the preservation of favoured races in the struggle for life. London: John Murray.

Darwin, C. (1871). The descent of man, and selection in relation to sex (Vol. 1). London: John Murray.

Del Lucchese, F. (2009). Monstrous individuations: Deleuze, Simondon, and relational ontology. Differences, 20, 179-193. https://doi.org/10.1215/10407391-2009-008

Deleuze, G. (1994). Desert islands. In G. Deleuze \& D. Lapoujade (Ed.) \& M. Taormina (Trans.), Desert islands and other texts: $1953-1974$ (pp. 9-14). Cambridge, MA: Semiotext(e) $\&$ MIT Press.

Deleuze, G. (2004) Difference and repetition. P. Patton (Trans.). London: Continuum.

Derrida, J. (2009). The beast and the sovereign. In M. Lisse, M.L. Mallet, \& G. Michaud (Eds.) \& G. Bennington (Trans.) (Vol. I). Chicago: University of Chicago Press.

Glendening, J. (2007). The evolutionary imagination in late-Victorian novels: an entangled bank. Aldershot: Ashgate.

Grosz, E. (2011). Becoming undone: Darwinian reflections on life, politics, and art. Durham, NC: Duke University Press. https://doi.org/10.1215/9780822394433

Houellebecq, M. (2007). The possibility of an island. G. Bowd (Trans.). New York: Vintage.

Huxley, A, (2005 [1962]). Island. D. Bradshaw (Ed.). London: Vintage.

Jameson, F. (2007). Archaeologies of the future: the desire called Utopia and other science fictions. London: Verso.

Levine, G. (1988). Darwin and the novelists: patterns of science in Victorian fiction. Cambridge, MA: Harvard University Press.

McCann, J. (2010). Michel Houellebecq: author of our times. Oxford: Peter Lang. https://doi.org/10.3726/978-3-0353-0012-3

Richter, V. (2011). Literature after Darwin: human beasts in western fiction 1859-1939. London: Palgrave Macmillan. https://doi.org/10.1057/9780230300446

Shaviro, S. (2010) interstitial life: remarks on causality and purpose in biology. In P. Gaffney (Ed.), The force of the virtual: Deleuze, science, and philosophy (pp. 133-147). Minneapolis: Minnesota University Press. https://doi.org/10.5749/minnesota/9780816665976.003.0005 
Shostak, S. (1999). Evolution of sameness and difference. Florida: CRC Press.

Shuttleworth, S. (1984). George Eliot and nineteenth-century science: the make-believe of a beginning. Cambridge: Cambridge University Press.

Smith, A. (2008 [1776]). An inquiry into the nature and causes of the wealth of nations. (K. Sutherland Ed.). Oxford: Oxford University Press.

Watt, I. (1957). The rise of the novel; studies in Defoe, Richardson, and Fielding. Berkeley: University of California Press.

Wells, H.G. (2005 [1896]) The island of Dr. Moreau P. Parrinder (Ed.). London: Penguin. 